\title{
Renewing the spirit
}

Seventy-five years ago, in the first pages of the first volume of the Journal of Clinical Investigation, Alfred E. Cohn proposed that this new journal "give expression" to "the spirit which has called the American Society for Clinical Investigation into being" (1). Cohn defined that new spirit as flowing from the growing self-consciousness of academic medicine, which recognized that its bailiwick was the "legitimate interest in learning as well as a means for furthering the methods which lead to the cure of disease." Three-quarters of a century later, that is still the raison d'être of the JCI. This has not and will not change.

But some things do change for this journal; you are either holding an example or looking at one on your computer screen. As Cohn pointed out in the JCI's first editorial, academic medicine is never unaffected by the world around it. And, as we have learned, neither is academic medical publishing. Beginning with this issue, we are taking into account the realities of new technology and trends, and are now publishing the Journal directly from our editorial office. We are very grateful to Rockefeller University Press for its years of service to the Society. Nevertheless, it became clear to both parties that the JCI should be published directly by its Society, which will realize both financial and scientific benefits. Financially, the Journal will be more economical to produce, and thus subscriptions, page charges, etc. will be held to a minimum. Scientifically, we will be able to even further reduce turnaround time from acceptance to publication, as we will have more direct control over deadlines and issue contents. Faster turnaround can only help the ongoing dialogue that defines the research enterprise.

There are other changes as well. As readers may already know (2), we are now accepting letters to the editor on the website. We also plan to continue our "fast track" approach to the reviewing and publishing of Rapid publications. In most cases, decisions regarding Rapids are now being completed within two weeks of receipt. We are also turning our attention toward providing a wider range of Editorials, Commentaries, and Perspectives in the "front" of the book, in order to give the greatest number of readers access to the first-rate science published in the "back." We are eager to hear your ideas on specific topics, and hope to cover a wide spectrum of interests.

As I outlined in my very first editorial (3), all of the members of the Editorial Board are keenly aware of the fact that this is not "our" journal, but rather your journal. If the changes we are implementing enhance the JCI's utility for you, that is precisely our goal. If there are problems, we want to know. It will undoubtedly take some time for the dust to settle following all this construction, but we think it is worth the effort. And, despite all these changes, it is not a new foundation we are building. As always, the Board meets weekly to review all submitted manuscripts. We continue to place considerable emphasis on our efforts to select those works for publica-

\section{Editorial}

PURPOSES IN MEDICAL RESEARCH

Astrodection to taz Jourasal of Cunical Isvestroumos BY ALFRFD F. COHN

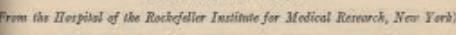
ustum hus variod in the histury of modical journalism; certain mals were introduced to their renders without explicit statement beir editors of the purposes which the new publications were Indere of the contemporary public to find within its poses cdge of the conterporary public to find within its pages cention for the new venture. Oeter journals have becn expicit huve disadvatnes, In a discipline us old as medicinc, whiges

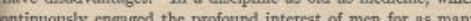
ries as has any of the other subjects in which men have ex many sity and the desire for knowiledre, it is fitting in the incercised inty and the of efinitcness and with the view of making an cxact statement of our of our contemporarice, to define the motives which sugerst this publication.

There is a pitfall here, which should be avoided In the attenpt There is a pitiall here, which should be avoided. In the attempt to explain the purposes which actuate the publication of a new journal,
the impulse may be, as Naunyn 1 pointed out in the case of Wunderthe impolse may be, as Naunyn ${ }^{1}$ pointed out in the case of Wunder-
lich, to mike too precise the limits within which the thou hht which lich, to make too precise the limits within which the thought which underlies the undertaking is to be contined. The doors in medicin must maturally be kept open so that influences, no mutter whence dorived, may contribute their share to the understanding and clucidacine. But that a danger lies here history has made oninly of medFor there has never been a time cither in the ancient or in the aparent. world when medicine wis for removed from the infuences of modern ${ }^{1}$ Naunya, B., Deut. Arch. $f$. klin. Mod, 1922, al, 1-27. Die deutsche Heil kunde vam Anfang des neunachnten Jahrhundert.

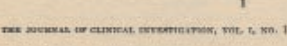

tion that not only pass muster with our external referees, but also those that will appeal to our broad readership. Prioritization is an inexact science, but we feel that the large expanse of research interests covered by our editors ensures proper balance for all disciplines. By keeping our eyes focused on our most important goal - the rapid dissemination of the best science possible - we strive to renew the spirit in which the JCI was founded and by which it has been guided for the past 75 years.

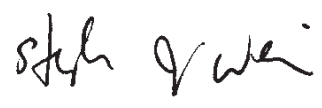

\section{Stephen J. Weiss}

\section{For the Editorial Board}

1. Cohn, A.E. 1924. Purposes in medical research: an introduction to the Journal of Clinical Investigation. J. Clin. Invest. 1:1-11.

2. Weiss, S.J. 1998. Rapids, consultants, letters, selfpublishing and more... "The more things change, the more they stay the same." J. Clin. Invest. 102:273.

3. Weiss, S.J. 1997. Speed, competition, rigor and creativity: striking a delicate balance. J. Clin. Invest. 99:817-818. 